\title{
Replacement meat by commercial flours on physicochemical and sensory properties of low-fat lamb burgers
}

\author{
Substituição da carne por farinhas comerciais nas propriedades físico-química e sensoriais de \\ hambúrgueres de cordeiro com baixo teor de gordura
}

Reemplazo de la carne por harinas comerciales sobre las propiedades fisicoquímicas y sensoriales de las hamburguesas de cordero bajas en grasa

Received: 10/14/2021 | Reviewed: 10/23/2021 | Accept: 11/09/2021| Published: 11/14/2021

Tamires Marcelino da Silva Felix ORCID: https://orcid.org/0000-0003-2120-5526 Universidade Federal da Paraíba, Brasil

E-mail: tamiresmarcelino30@hotmail.com

Francisco Allan Leandro de Carvalho

ORCID: https://orcid.org/0000-0002-4097-0146 Universidade Federal do Vale do São Francisco, Brasil E-mail: francisco.allan@univasf.edu.br

Ery Jonhons Nascimento Ramos

ORCID: https://orcid.org/0000-0002-3520-9133 Universidade Federal do Vale do São Francisco, Brasil E-mail: eryjonhons@gmail.com

Bernardo José Marques Ferreira

ORCID: https://orcid.org/0000-0003-0386-4085 Universidade Federal do Vale do São Francisco, Brasil

E-mail: bernardo.zootecnista@gmail.com

Rafael Torres de Souza Rodrigues

ORCID: https://orcid.org/0000-0002-6436-8299 Universidade Federal do Vale do São Francisco, Brasil E-mail: rafael.rodrigues@univasf.edu.br Mário Adriano Ávila Queiroz ORCID: https://orcid.org/0000-0001-7677-5273 Universidade Federal do Vale do São Francisco, Brasil E-mail: mario.queiroz@univasf.edu.br

\begin{abstract}
The effect of incorporating of breadcrumbs, oatmeal and cassava starch on the physicochemical and sensorial parameters of low-fat lamb burgers were investigated. Seven treatments were prepared: control (CONT), $2 \%$ or $4 \%$ addition of breadcrumbs (BRE2 and BRE4), oatmeal flour (OAT2 and OAT4) and cassava flour (CAS2 and CAS4); and analyzed their physicochemical parameters (moisture, protein, fat, ash, carbohydrate, energy, water holding capacity and cooking loss). Furthermore, consumers evaluated the sensory acceptance (color, taste, texture, aroma and overall quality) and indicated their preference. The treatments affected the characteristics of the product $(\mathrm{P}<0.05)$, the highest values of fat $(12.26 \%)$ carbohydrate $(2.83 \%)$, energy (194.39Kcal/100g) and cooking loss $(54.90 \%)$ were found in CAS2, CAS4, OAT4 and BRE2, respectively. CAS2 group improved the taste, while BRE4 improved the texture and along with CAS4 were the batches most preferred by consumers (18.8\% and $21.5 \%$, respectively). Breadcrumbs and cassava flour are most recommended for low-fat lamb burger production.
\end{abstract}

Keywords: Breadcrumbs; Cassava; Flour; Oatmeal; Starch.

\section{Resumo}

Objetivou-se investigar o efeito da incorporação de farinha de rosca, farinha de aveia e amido de mandioca sobre os parâmetros físico-químicos e sensoriais de hambúrgueres com baixo teor de gordura. Foram preparados sete tratamentos: controle (CONT), adição de $2 \%$ ou $4 \%$ de farinha de rosca (BRE2 e BRE4), farinha de aveia (OAT2 e OAT4) e farinha de mandioca (CAS2 e CAS4); e analisou-se os parâmetros físico-químicos (umidade, proteína, gordura, cinzas, carboidratos, energia, capacidade de retenção de água e perda por cozimento). Além disso, os consumidores avaliaram a aceitação sensorial (cor, sabor, textura, aroma e qualidade geral) e indicaram sua preferência. Os tratamentos afetaram as características do produto $(\mathrm{P}<0,05)$, os maiores valores de gordura $(12,26 \%)$, 
carboidratos $(2,83 \%)$, energia $(194,39 \mathrm{Kcal} / 100 \mathrm{~g})$ e perda por cozimento $(54,90 \%)$ foram encontrados em CAS2, CAS4, OAT4 e BRE2, respectivamente. O grupo CAS2 apresentou melhor sabor, enquanto o BRE4 melhor textura e junto com o CAS4 foram os lotes mais preferidos pelos consumidores (18,8\% e 21,5\%, respectivamente). Farinha de rosca e farinha de mandioca são os mais recomendados para a produção de hambúrguer de cordeiro com baixo teor de gordura.

Palavras-chave: Amido; Aveia; Farinha; Farinha de rosca; Mandioca.

\section{Resumen}

El objetivo fue investigar el efecto de la incorporación de harina de pan, harina de avena y almidón de yuca sobre los parámetros fisicoquímicos y sensoriales de las hamburguesas bajas en grasa. Se prepararon siete tratamientos: control (CONT), adición de harina de pan al 2\% o 4\% (BRE2 y BRE4), harina de avena (OAT2 y OAT4) y harina de yuca (CAS2 y CAS4); y se analizaron los parámetros fisicoquímicos (humedad, proteínas, grasas, cenizas, carbohidratos, energía, capacidad de retención de agua y pérdida de cocción). Además, los consumidores evaluaron la aceptación sensorial (color, sabor, textura, aroma y calidad general) e indicaron su preferencia. Los tratamientos afectaron las características del producto $(\mathrm{P}<0.05)$, los valores más altos de grasa $(12.26 \%)$, carbohidratos $(2.83 \%)$, energía (194.39Kcal / 100g) y pérdida de cocción $(54,90 \%)$ se encontraron en CAS2, CAS4, OAT4 y BRE2, respectivamente. El grupo CAS2 tuvo mejor sabor, mientras que BRE4 tuvo mejor textura y junto con CAS4 fueron los lotes más preferidos por los consumidores $(18,8 \%$ y $21,5 \%$, respectivamente). La harina de pan y harina de yuca son los más recomendados para la elaboración de hamburguesas de cordero bajas en grasa.

Palabras clave: Almidón; Avena; Harina; Harina de pan; Mandioca.

\section{Introduction}

Burgers are traditional meat products, widely consumed in several countries, and conventional burger contains up to $30 \%$ fat (Heck et al., 2017; Bastos et al., 2014). This fat plays an important role in the cooking loss, retention capacity of water, succulence, texture and physicochemical properties of the products. However, there are relevant concerns about the fat and levels in meats and meat products. Many consumers are aware of the health risks from frequent consumption of animal fat, resulting a growing demand for low fat products (Da Silva et al., 2019).

Growing consumer interest in healthy products has created a potential market for meat products with healthier attributes. The market has been demanding new products that focus on reducing fat for a healthier diet. As a result, there is a strong interest in the development of products with these characteristics. This fat reduction/removal, however, may bring about changes in technological properties, such as texture profile and the presence of exudate liquid, in addition to changes in sensory properties (Weiss et al., 2010).

The challenge is to produce low-fat lamb burger without compromising on expected product characteristics. In addition, it is necessary to understand consumers' perceptions and attitudes towards new products to achieve proper product positioning (Carrillo, Varela, Salvador, \& Fiszman, 2011; Furst, Connors, Bisogni, Sobal, Falk, 1996).

Several studies have evaluated the reduction of animal fat added and the incorporation of flour in low-fat meat products (Ali, El-Anany \& Gaafar, 2011; Trevisan et al., 2016; Bastos et al., 2014) to compensate for possible losses by fat removal. The aim of this study was to evaluate the effect of incorporating different sources and levels of commercial flour (breadcrumbs, cassava starch and oatmeal) on the physicochemical and sensory characteristics of low fat lamb burgers.

\section{Methodology}

\subsection{Burger manufacture}

Seven batches of lamb patties with two levels of commercial flour (breadcrumbs, cassava and oatmeal) were manufactured in the Federal University of San Francisco Valey, Petrolina-PE, Brazil, the ingredients used in the formulations are presented in Table 1. A total of 56 burgers, weighing approximately $100 \mathrm{~g}$ each, were produced (7 treatments $\mathrm{x} 8$ samples for each batch). The seven treatments studied were control (CONT; without flour); with $2 \%$ or 
$4 \%$ of breadcrumbs (BRE2 and BRE4), cassava flour (CAS2 and CAS4) and oatmeal (OAT2 and OAT4) were added. To produce the patties, lamb meat was ground through $8 \mathrm{~mm}$ diameter mincing plate in a mincer machine (Bermar, BM 20, São Paulo Brazil). The meat mass was separated into seven batches and the respective type and amount of flour was added to each batch, mixed, and compressed manually. These seven mixed masses were kept at $4 \pm 2^{\circ} \mathrm{C}$ for 6 $\mathrm{h}$ and then lamb burgers were produced in molds of $10 \mathrm{~cm}$ in diameter and $1 \mathrm{~cm}$ in height approximately.

Table 1. Formulation of the seven lamb burgers prepared with commercial flour.

\begin{tabular}{lccccccc}
\hline Ingredients g/100g & CONT & BRE2 & BRE4 & CAS2 & CAS4 & OAT2 & OAT4 \\
\hline Lamb meat & 92.77 & 90.75 & 88.71 & 90.75 & 88.71 & 90.75 & 88.71 \\
Garlic powder & 0,50 & 0,50 & 0,50 & 0,50 & 0,50 & 0,50 & 0,50 \\
Onion powder & 0,50 & 0,50 & 0,50 & 0,50 & 0,50 & 0,50 & 0,50 \\
Fine herbs* & 0,15 & 0,15 & 0,15 & 0,15 & 0,15 & 0,15 & 0,15 \\
Pepper & 0,10 & 0,10 & 0,10 & 0,10 & 0,10 & 0,10 & 0,10 \\
Salt & 2,5 & 2,5 & 2,5 & 2,5 & 2,5 & 2,5 & 2,5 \\
Textured soy fiber & 3,5 & 3,5 & 3,5 & 3,5 & 3,5 & 3,5 & 3,5 \\
Breadcrumbs & - & 2 & 4 & - & - & - & - \\
Cassava flour & - & - & - & & 2 & - & - \\
Oatmeal flour & - & - & - & - & - & 2 & 4 \\
\hline
\end{tabular}

*Parsley, oregano, basil and chives. CONT: control. BRE2: $2 \%$ of breadcrumbs. BRE4: $4 \%$ of breadcrumbs. OAT2: $2 \%$ of oatmeal flour. OAT4: $4 \%$ oatmeal flour. CAS2: $2 \%$ cassava flour. CAS4: $4 \%$ cassava flour. Source: Authors.

\subsection{Physicochemical characteristics}

Moisture, protein and ash were determined following by the AOAC recommendations (950.46:2005; 2011.04:2005 and 920.153:2005, respectively), the fat amount was extracted according to the AOCS Official Procedure Am 5-04 (AOCS, 2009). The carbohydrate content was calculated by the difference of the aforementioned contents, while energy content was estimated based on $9 \mathrm{kcal} / \mathrm{g}$ for fat and $4 \mathrm{kcal} / \mathrm{g}$ for protein and carbohydrate. Water retention capacity (WRC) was carried out according to Hamm, (1960), while cooking loss (CL) and shrinkage were obtained by the difference in weight and diameter, respectively, between the raw and cooked samples $\left(72^{\circ} \mathrm{C}\right)$.

For $\mathrm{pH}$ measurement of burgers, a penetration $\mathrm{pH}$ meter previously calibrated was used (TESTO 205). The color parameters were determined using a portable colorimeter (CR-400, Konica Minolta, Osaka, Japan), set to pulsed xenon arc lamp, $10^{\circ}$ viewing angle geometry, and $8 \mathrm{~mm}$ aperture, using the CIE lab system: L* (lightness), $\mathrm{a}^{*}$ (redness) and $\mathrm{b}^{*}$ (yellowness).

Texture parameters were obtained using a texture analyser TA.XT2 Express (Stable Micro Systems, Surrey, UK), equipped with cylindrical probe with flat surface area of $19.85 \mathrm{~cm}^{2}$ ). Texture profile analysis (TPA) (hardness, springiness, cohesiveness and chewiness) was carried out in burgers slices of $2 \mathrm{~cm}$ for two compression cycles at $50 \%$ with a compression speed of $3.33 \mathrm{~mm} / \mathrm{s}$.

\subsection{Sensory analysis}

The Human Research Ethics Committee (CEP-UNIVASF protocol number 62667316.2.000.5196) approved this research. A total of 114 consumers (55\% female and 45\% male, were aged between 18 and 41 years) selected from Petrolina (Brazil) carried out sensory analysis. An acceptance test was performed in individual booths. The panelists were 
asked to evaluate the following sensory attributes in cooked burgers (color, taste, aroma, texture and overall quality) using a hedonic scale with 9 points $(1=$ strongly dislike and $9=$ strongly like $)$.

In addition, the panelists were asked to indicate their preference. The burgers were cooked in a grill (Mondial Smart G-04, Barueri, Brazil), until reaching an internal temperature of $72{ }^{\circ} \mathrm{C}$. Samples were presented to panelists on plastic plates encoded with random 3-digit numbers (MacFie, Bratchell, Greenhoff \& Vallis, 1989). Water and unsalted toasted bread were served to clean the palate and remove the residual flavors, at the beginning of the sessions and between the samples.

Sensory analyzes were performed after the microbial safety evaluation of the samples (results not shown), according to the Brazilian regulation for frozen raw meat products (BRAZIL. Ministry of Health, National Health Surveillance Agency, Resolution RDC n 12, 2001) counts were within the established limits for the pathogens.

\subsection{Statistical analysis}

A completely randomized design was used with seven treatments (CONT, BRE2, BRE4, CAS2, CAS4, OAT2, and OAT4) and eight replications per treatment. These 56 hamburgers were analyzed in triplicate, total $\mathrm{n}=$ 168. Previously normal distribution and variance homogeneity were tested (Shapiro-Wilk). The data were submitted to oneway analysis of variance (ANOVA; with treatment as a fixed effect) followed by Tukey's test when the ANOVA was significant $(P<0.05)$. For sensory data, Friedman two-way analysis of variance by ranks test was applied (with batch as a fixed effect and panelist as random effect), followed by Wilcoxon test with Bonferroni correction for pairwise multiple comparisons when significant differences were detected between treatments $(P<0.05)$. Statistical analyzes were carried out using software R version 3.2.4.

\section{Results and Discussion}

\subsection{Physicochemical characteristics}

The effect of flour addition on proximate composition and energy content of lamb burgers are shown in Table 2. The incorporation of flour affected $(\mathrm{P}<0.001)$ the proximate composition, moisture content changing from $64.23 \%$ to $66.96 \%$ in OAT4 and BRE2 respectively. Only batches with added oatmeal (OAT2 and OAT4) decreased the moisture content showing values lower than CONT, probably due to the higher amount of dry matter in oatmeal. This result agree with data reposted by Heck et al (2017), who found similar moisture content in the low-fat burger.

Table 2. Proximate composition of lamb patties prepared with commercial flour.

\begin{tabular}{lccccccccc}
\hline & CONT & BRE2 & BRE4 & CAS2 & CAS4 & OAT2 & OAT4 & SE & Sig. \\
\hline Proximate composition $(\mathrm{g} / 100 \mathrm{~g})$ & & & & & & & & \\
Moisture & $66.78^{\mathrm{a}}$ & $66.93^{\mathrm{a}}$ & $66.74^{\mathrm{a}}$ & $66.06^{\mathrm{a}}$ & $65.95^{\mathrm{a}}$ & $64.70^{\mathrm{b}}$ & $64.23^{\mathrm{b}}$ & 0.22 & $* * *$ \\
Fat & $10.35^{\mathrm{e}}$ & $10.86^{\mathrm{de}}$ & $11.54^{\mathrm{bc}}$ & $12.26^{\mathrm{a}}$ & $11.13^{\mathrm{cd}}$ & $11.62^{\mathrm{bc}}$ & $11.71^{\mathrm{b}}$ & 0.12 & $* * *$ \\
Protein & 20.59 & 21.22 & 21.28 & 19.34 & 18.81 & 19.79 & 20.63 & 0.25 & $\mathrm{~ns}$ \\
Ash & 1.80 & 1.86 & 1.86 & 1.74 & 1.76 & 1.86 & 1.82 & 0.02 & $\mathrm{~ns}$ \\
Carbohydrate & $0.72^{\mathrm{bc}}$ & $0.36^{\mathrm{c}}$ & $0.37^{\mathrm{c}}$ & $0.59^{\mathrm{c}}$ & $2.83^{\mathrm{a}}$ & $2.59^{\mathrm{ab}}$ & $2.05^{\mathrm{abc}}$ & 0.27 & $* *$ \\
$\begin{array}{l}\text { Energy } \\
\text { (Kcal/100g) }\end{array}$ & $177.65^{\mathrm{c}}$ & $182.99^{\mathrm{bc}}$ & $188.90^{\mathrm{ab}}$ & $190.10^{\mathrm{ab}}$ & $186.70^{\mathrm{ab}}$ & $190.43^{\mathrm{ab}}$ & $194.39^{\mathrm{a}}$ & 1.19 & $* * *$ \\
\hline
\end{tabular}

${ }^{a-d}$ Different lowercase letters in the same row indicate significant difference. SE: Standard error. Sig.: significance. ns.: not significant. $* \mathrm{P}<0.05$. $* * \mathrm{P}<0.01$. $* * * \mathrm{P}<0.001$. CONT: control. BRE2: $2 \%$ of breadcrumbs. BRE4: $4 \%$ of breadcrumbs. OAT2: $2 \%$ of oatmeal flour. OAT4: $4 \%$ oatmeal flour. CAS2: $2 \%$ cassava flour. CAS4: $4 \%$ cassava flour. Source: Authors. 
Fat content was also influenced by flour addition $(\mathrm{P}<0.05)$, CONT showed the lowest value $(10.35 \%)$, while flour addition in BRE4, CAS2, CAS4, OAT2 and OAT4 increased the fat content andCAS2 presented the highest value (12.26\%). This result is in agreement with Trevisan et al. (2016), who found a similar value (12.28\%) in low-fat beef burger with $3 \%$ oat fiber added. The incorporation of flour in low-fat burgers did not affect the protein and ash contents, which ranged from $18.81 \%$ to $21.28 \%$ and from $1.74 \%$ to 1.86 in CAS2 and BRE2, respectively.

Unsurprisingly, the carbohydrate content increased $(\mathrm{P}<0.001)$ with flour addition ranging between $0.36 \%$ in $\mathrm{BRE} 2$ and $2.59 \%$ in CAS4. This can be explained by the amount of carbohydrate of the flours, which is higher than in lamb meat that has been replaced, and agree with data reported by Oliveira et al. (2014) who studied the effect de linseed flour on beef burgers.

Regarding energy content, batches with flour addition presented the higher values compared to CONT $(\mathrm{P}<0.0001)$, ranging from $177.65 \mathrm{Kcal} / 100 \mathrm{~g}$ to $194.39 \mathrm{Kcal} / 100 \mathrm{~g}$; OAT4 showed the highest value. This increase could be related to lower moisture content in these treatments, which changes the proportion of the other components, especially the fat that gives the most energy. This finding is in agrément with data reported by other authors who noticed similar energy values with flour incorporation in beef burgers (Ali, El-Anany \& Gaafar, 2011; Oliveira et al. 2014).

The addition of flours affected the $\mathrm{pH}$ of lamb burgers $(\mathrm{p}<0.05)$. There was a tendency for the $\mathrm{pH}$ to decrease with the increase in the level of added flour. However, only BRE4 with a lower value (5.94) differed from CONT treatment (6.00). Lower $\mathrm{pH}$ increases water holding capacity and juiciness and reduces cooking losses as well as shrinkage (Table $3)$.

Table 3. Water retention capacity (WRC), cooking loss (CL) and texture profile analysis of lamb patties prepared with commercial flour.

\begin{tabular}{|c|c|c|c|c|c|c|c|c|c|}
\hline & CONT & BRE2 & BRE4 & CAS2 & CAS4 & OAT2 & OAT4 & $\mathrm{SE}$ & Sig. \\
\hline WRC (\%) & 83.68 & 85.87 & 87.60 & 87.21 & 86.46 & 84.81 & 84.03 & 0.48 & ns \\
\hline CL (\%) & $10.08^{\mathrm{a}}$ & $8.60^{\mathrm{b}}$ & $6.87^{\mathrm{cd}}$ & $7.77^{b c}$ & $6.88^{\mathrm{cd}}$ & $8.44^{\mathrm{b}}$ & $6.35^{\mathrm{d}}$ & 1.86 & $* * *$ \\
\hline Shrinkage (\%) & $18.60^{\mathrm{a}}$ & $12.54^{\mathrm{b}}$ & $7.10^{\mathrm{c}}$ & $9.21^{\mathrm{c}}$ & $7.79^{\mathrm{c}}$ & $8.70^{\mathrm{c}}$ & $8.65^{\mathrm{c}}$ & 1.03 & $* * *$ \\
\hline Hardness (\%) & 10.60 & 9.78 & 10.24 & 10.72 & 9.89 & 11.34 & 11.70 & 0.35 & ns \\
\hline Springiness (mm) & 0.90 & 0.85 & 0.81 & 0.85 & 0.81 & 0.83 & 0.83 & 0.01 & ns \\
\hline Cohesiveness & 0.74 & 072 & 0.69 & 0.68 & 0.74 & 0.72 & 0.71 & 0.01 & ns \\
\hline Chewiness (Kg.mm) & 6.41 & 5.70 & 5.67 & 6.16 & 5.89 & 6.76 & 7.44 & 0.19 & ns \\
\hline
\end{tabular}

${ }^{a-d}$ Different lowercase letters in the same row indicate significant difference. SE: Standard error. Sig.: significance. ns.: not significant. $* \mathrm{P}<0.05$. $* * \mathrm{P}<0.01$. $* * * \mathrm{P}<0.001$. CONT: control. BRE2: $2 \%$ of breadcrumbs. BRE4: $4 \%$ of breadcrumbs. OAT2: $2 \%$ of oatmeal flour. OAT4: $4 \%$ oatmeal flour. CAS2: $2 \%$ cassava flour. CAS4: $4 \%$ cassava flour. Source: Authors.

This is because the $\mathrm{pH}$ influences the electrostatic relationships between proteins, which allows the repulsion between the polypeptide chains, increasing the spaces between the filaments and thereby expanding the water retention capacity (Ordóñez, 2005). Regarding the color parameters, there was no difference for $a^{*}$ and $b^{*}(p>0.05$ ). While L* values were affected by the inclusion of flours ranging from 39.21 in BRE2 to 43.48 in CAS4, but no treatment differed from the control (Table 4). 
Table 4. $\mathrm{pH}$ and color parameters of lamb patties prepared with commercial flour.

\begin{tabular}{|c|c|c|c|c|c|c|c|c|c|}
\hline & CONT & BRE2 & BRE4 & CAS2 & CAS4 & OAT2 & OAT4 & SE & Sig \\
\hline $\mathrm{pH}$ & $6.00^{\mathrm{ab}}$ & $6.00^{\mathrm{ab}}$ & $5.95^{b}$ & $5.99^{\mathrm{ab}}$ & $5.94^{b}$ & $6.05^{\mathrm{a}}$ & $5.99^{\mathrm{ab}}$ & 0.02 & $* *$ \\
\hline $\mathrm{L}^{*}$ & $41.50^{\mathrm{ab}}$ & $39.21^{\mathrm{b}}$ & $42.95^{\mathrm{ab}}$ & $42.41^{\mathrm{ab}}$ & $43.48^{\mathrm{a}}$ & $41.00^{\mathrm{ab}}$ & $42.65^{\mathrm{ab}}$ & 1.42 & $*$ \\
\hline$a^{*}$ & 8.85 & 8.61 & 7.39 & 8.55 & 7.79 & 8.09 & 8.25 & 0.98 & ns \\
\hline$b^{*}$ & 18.57 & 17.09 & 17.36 & 16.90 & 18.70 & 16.51 & 18.34 & 0.96 & ns \\
\hline
\end{tabular}

${ }^{\text {a-d }}$ Different lowercase letters in the same row indicate significant difference. SE: Standard error. Sig.: significance. ns.: not significant. ${ }^{*} \mathrm{P}<0.05$. $* * \mathrm{P}<0.01$. ${ }^{*} * * \mathrm{P}<0.001$. CONT: control. BRE2: $2 \%$ of breadcrumbs. BRE4: $4 \%$ of breadcrumbs. OAT2: $2 \%$ of oatmeal flour. OAT4: $4 \%$ oatmeal flour. CAS2: $2 \%$ cassava flour. CAS4: $4 \%$ cassava flour. Source: Authors.

Araujo et al (2020) reported similar L * values to those found in our study. WHC is a meat property that describes the ability to retain water through self-structuring. It is a technological parameter used by the meat industry since is related to post-slaughter weight loss, quality and yield of meat and meat products (Bastos et al. 2014). In the present study, the flour incorporation did not affect the water-holding capacity ( $\mathrm{p}>0.05$ ), which ranged from 83.68\% to $87.60 \%$.

However, they were higher than the values reported by Oliveira et al. (2014) and Bastos et al. (2014), in beef burgers. This result was not expected, as one of the advantages of incorporating flours into meat products is their ability to retain water in these foods. So possibly higher levels of flour inclusion would be needed to affect WHC. On the other hand, the addition of flour had a significant effect on cooking loss (CL), which ranged between $6.35 \%$ and $10.08 \%$ in the OAT4 and CONT groups, respectively.

Burgers with the highest level of inclusion had the lowest losses, according to Aleson-Carbonell et al. (2005), the loss of water during cooking may affect the juiciness and tenderness. In addition, sensory attributes such as color, texture and acceptability depend on the product's capacity to not lose water (Morón-Fuenmayor and Zamorano-García 2004; Hautrive et al. 2008).

There was a reduction in shrinkage with the addition of flours $(\mathrm{p}<0.05)$, varying from 7.10 in BRE4 to 18.60 in CONT. All groups had less shrinkage than the CONT group, but only for BRE treatments, the increase in the level of inclusion resulted in less shrinkage, comparing 2 or $4 \%$ addition. This result is related to the $\mathrm{pH}$ values mentioned above. Although the texture profile has not changed, lower cooking losses and shrinkage represent a higher yield in the cooked product, a desirable characteristic for industry and consumers.

The addition of flours at the two inclusion levels tested ( 2 and $4 \%$ ) did not affect the texture profile of the hamburgers $(\mathrm{p}>0.05)$. This fact is important from an industrial points of view, as it has a direct relationship with the acceptance of the product by consumers (Carvalho et al., 2020). When a reduction in flavor (taste and smell) is observed due to the reduction of any food ingredient in the traditional meat product formulations, consumers tend to reject the product. The development of meat products with low fat content acceptable to the consumer is a challenge, as fat provides desirable quality attributes (Kumar, 2019), especially texture.

\subsection{Sensory analysis}

Regarding sensory analysis, all treatments received an acceptance test score higher than 5 (acceptability limit of the hedonic scale used in this study) indicating that it is possible to produce lamb burger without fat added and that adding of flour does not alter the acceptability of low-fat lamb burger (Figure 1). In addition, no difference was observed in the aroma (A), color (B) and overall quality (E) of the burgers ( $\mathrm{p}>0.05$ ), which ranged from 6.88 to 7.19, from 7.08 to 7.32, and from 6.77 to 7.10 , respectively. 
This is a positive result since the addition of flour has not negatively changed the burgers color and the decision to purchase meat and products is greatly influenced by color (Carvalho et al. 2019). The incorporation of the flours affected the taste and texture $(\mathrm{p}<0.05)$. While BRE2 received the highest score $(6.99)$, OAT2 had the lowest score for taste (6.43), though, both did not differ from the control (Figure 1C).

According to Brewer (2012), incorporating flours into meat products usually adds unwanted flavors. However, the levels of flour tested in the present study were not sufficient to compromise the taste of the lamb burger. Similarly, texture score was higher in the sample containing $4 \%$ breadcrumbs (7.36) and lower in samples containing 2 and $4 \%$ oatmeal (7.04 and 6.96, respectively), being comparable to the control (Figure 1D).

Figure 1. Sensory scores (A-E) and preference (F) assigned by panelists for low-fat lamb patties produced with $2 \%$ or $4 \%$ of commercial flour (breadcrumbs, cassava starch and oatmeal). Different letters indicate a significant difference between the treatments.
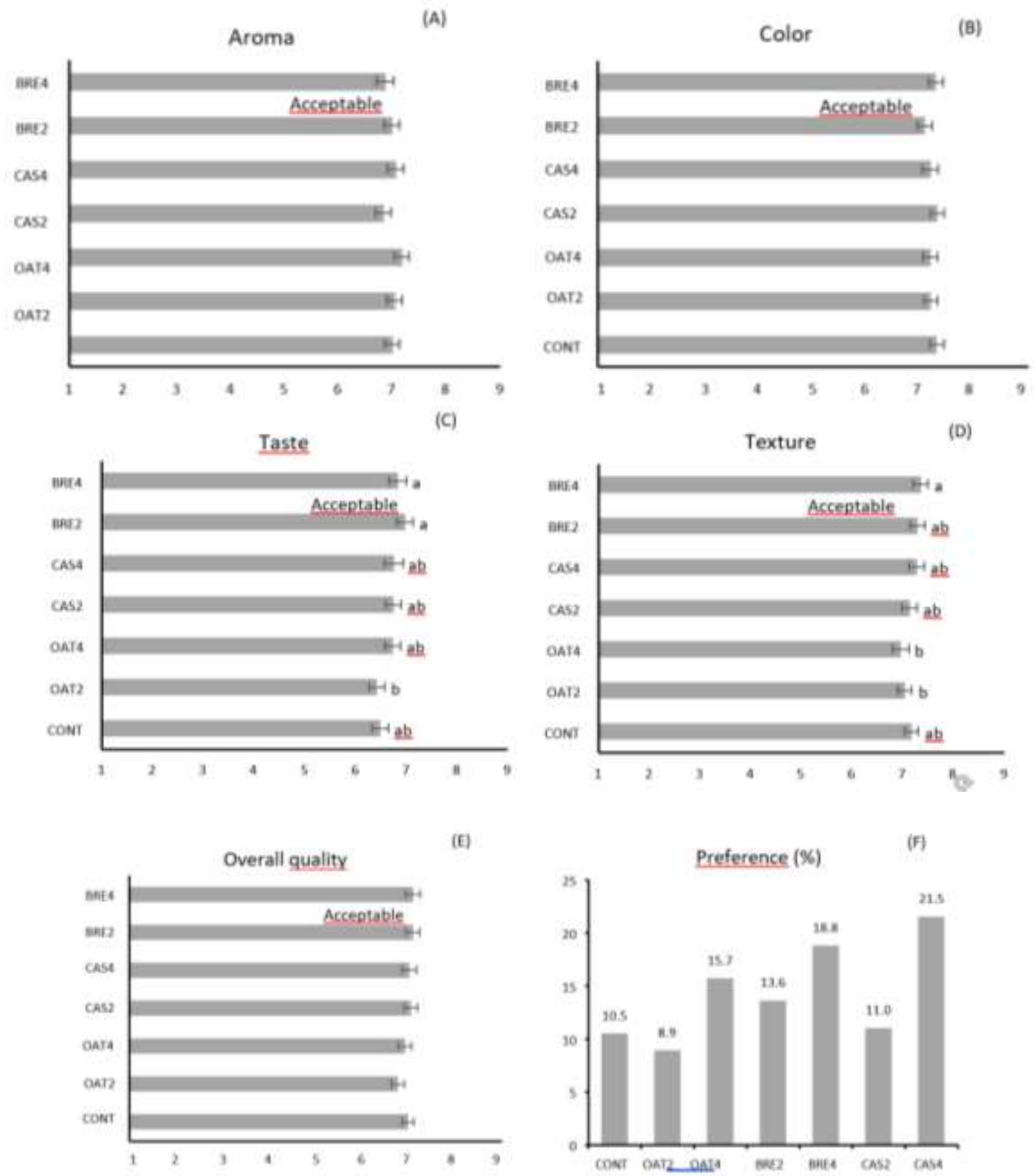

Source: Authors. 
These results highlight the possibilities of using flours for the production of burgers without sensory damage even in products with reduced fat content. Concerning the preference (Figure 1F), batches with higher levels of flour received higher scores, most of the panelists chose CAS4 (21.5\%) followed by BRE4 (18.8\%) and OAT4 (15.7\%) (Figure 1). The OAT2 and CONT groups were the least preferred (8.9\% and 10.5\%, respectively).

This result may be related to the lower cooking losses were observed in the respective treatments. Indicating that this variable can be decisive for consumer preference. In addition, this fact confirms the improvement in taste and texture in these batches and highlighting the influence of these attributes on the preference of products. The means of preference scores can allow determining consumer acceptance Kim, Greve, and Lee (2016).

\section{Conclusion}

This study demonstrated that it is possible to produce low-fat lamb hamburgers by incorporating commercial flours, without compromising or improving the sensory physical-chemical characteristics. The incorporation of flour reduced losses due to cooking and shrinkage of hamburgers, technological properties of interest to the industry. In addition, breadcrumb treatments obtained the highest scores for taste and texture sensory attributes. Burgers with the highest inclusion of flour (4\%) were the most preferred by the tasters.

\section{Acknowledgements}

Thanks to CNPq (Conselho Nacional de Desenvolvimento Científico e Tecnológico) for supporting this research (grant number 482971/2013-4).

\section{References}

Aleson-Carbonell, L., Fernández-López, J., Pérez-Alvarez, J. A., Kuri, V. (2005). Characteristics of beef burger as influenced by various types of lemon albedo. Innovative Food Science and Emerging Technologies, 6, 247-255.

Ali, R. F. M, El-Anany, A. M., Gaafar, A. M. (2011). Effect of potato flakes as fat replacer on the quality attributes of low-fat beef patties. International Journal of Food Science and Technology, 3, 173-180.

Association Official Analytical Chemist [AOAC]. (2005). Official Methods of Analysis (18th ed.). AOAC International.

American Oil Chemists' Society [AOCS].(2009).Official Methods and Recommendations Practices of AOCS. Denver, CO: AOCS.

Araujo, D. H. S., Rodrigues, R. T. S., Costa, M. M., Miranda, J. O., Lira-Alencar, N. R. C., Queiroz, M. A. A., Gois, G. C. (2020). Reduction of sodium content in frozen goat sausage using diferent types of salt. Lebensmittel-Wissenschaft \& Technologie-Food Science and Technology, 135, 110272. http://dx.doi.org/10.1016/j.1wt.2020.110272.

Bastos, S. C., Pimenta, M. E. S. G., Pimenta, C. J., Reis, T. A., Nunes, C. A., Pinheiro, A. C. M., ...Leal, R. S. (2014). Alternative fat substitutes for beef burger: Technological and sensory characteristics. Journal of Food Science and Technology, 51(9), 2046-2053. http://dx.doi.org/10.1007/s13197-013-1233-2.

BRASIL. Ministério da Saúde. Agência Nacional da Vigilância Sanitária. Resolução RDC n 12 , de 02 de janeiro de 2001. Aprova o regulamento técnico sobre padrões microbiológicos para alimentos. Diário Oficial da União, Brasília, 10 de janeiro de 2001.

Carrillo, E., Varela, P., Salvador, A., \& Fiszman, S. (2011). Main factors underlying consumers' food choice: a first step for the understanding of attitudes toward "healthy eating". Journal of Sensory Studies, 26 (2), 85-95. http://dx.doi.org/10.1111/j.1745-459X.2010.00325.x.

Carvalho, F. A. L., Lorenzo, J. M., Pateiro, M., Bermúdez, R., Purriños, L., Trindade, M. A, (2019). Effect of guarana (Paullinia cupana) seed and pitanga (Eugenia uniflora L.) leaf extracts on lamb burgers with fat replacement by chia oil emulsion during shelf life storage at $2{ }^{\circ} \mathrm{C}$. Food Research International, 125, 108554. https://doi.org/10.1016/j.foodres.2019.108554.

Carvalho, F. A. L., Munekata, P. E. S., Pateiro, M., Campagnol, P. C. B., Dominguez, R., Trindade, M. A., Lorenzo, J. M. (2020). Effect of replacing backfat with vegetable oils during the shelf-life of cooked lamb sausages. Lebensmittel-Wissenschaft \& Technologie - Food Science and Technology, 122 (2020), 109052. https://doi.org/10.1016/j.lwt.2020.109052.

Da Silva S. L., Amaral, J. T., Ribeiro, M., Sebastião, E. E., Vargas, C., De Lima, F. F., Campagnol, P.C.B., (2019). Fat replacement by oleogel rich in oleic acid and its impact on the technological, nutritional, oxidative, and sensory properties of Bologna-typesausages. MeatScience, 149, 141-148. 
https://doi.org/10.1016/j.meatsci.2018.11.020.

Furst, T., Connors, M., Bisogni, C. A., Sobal, J., Falk, L. W. (1996). Food choice: aconceptual model of the process. Appetite, 26, 247-265. http://dx.doi.org/10.1006/appe.1996.0019.

Hamm, R. Biochemistry of meat hydratation. Advances in Food Research, 10 (2), 335-443, 1960.

Hautrive, T. P., Oliveira, F. R., Silva, A. R. D., Terra, N. N., Campagnol, P. C. B. (2008). Physicochemical and sensorial analyses of ostrich hamburger. Revista Ciência e Tecnologia de Alimentos, 28, 95-101.

Heck, R. T., Vendruscolo, R. G., de Araújo Etchepare, M., Cichoski, A. J., de Menezes, C. R., Barin, J. S., Campagnol, P. C. B. (2017). Is it possible to produce a low-fat burger with a healthy $n-6 / n-3$ PUFA ratio without affecting the technological and sensory properties? Meat Science, 130 , 1625. https://doi.org/10.1016/j.meatsci.2017.03.010.

Kim, M. K., Greve, P., \& Lee, Y. (2016). Identification of drivers of liking for bar-type snacks based on individual consumer preference. Journal of Food Science, 81(1), S174-S181. https://doi.org/10.1111/1750-3841.13154.

Kumar, Y. (2019). Development of Low-Fat/Reduced-Fat Processed Meat Products using Fat Replacers and Analogues. Food Reviews International, DOI: $10.1080 / 87559129.2019 .1704001$

MacFie, H. J., Bratchell, N., Greenhoff, K., \& Vallis, L. V. (1989). Designs to balance the effect of order of presentation and first-order carry-over effects in Hall tests. Journal of Sensory Studies, 4(2), 129-148. https://doi.org/10.1111/j.1745459X.1989.tb00463.X.

Morón-Fuenmayor, O. E., Zamorano-García, L. (2004). Drip loss in raw meat of different animal types. Revista Científica de Veterinaria, 14, 3639.

Ordóñez, J. A. (2005). Tecnologia de alimentos: alimentos de origem animal. Artmed, 2, cap.12, 280p.

Oliveira, D. F., Mileski de, J. P. F., De Carli, C. G., Marchi, J. F., Silva, D. C., Coelho, A. R., Tonial, I. B. (2014). Farinha de linhaça dourada como substituto de gordura animal em hambúrguer de carne bovina com redução de sódio. Brazilian Journal of Food Technology, 17(4), $273-282$.

Trevisan, Y. C., Bis, C. V., Henck, J. M., \& Barretto, A. C. S. (2016). Effect of the addition of oat fiber on the physicochemical properties of cooked frozen hamburger with reduced fat and salt. Brazilian Journal of Food Technology, 19. http://dx.doi.org/10.1590/1981-6723.7915.

Weiss, J., Gibis, M., Schuh, V., \& Salminen, H. (2010). Advances in ingredient and processing systems for meat and meat products. Meat Science, 86, 196-213. http://dx.doi.org/10.1016/j.meatsci.2010.05.008. 